\title{
Chapter 25 \\ Innovative Partnerships to Scale Up \\ Climate-Smart Agriculture for Smallholder \\ Farmers in Southern Africa
}

\author{
Mariam A. T. J. Kadzamira and Oluyede C. Ajayi
}

\subsection{Introduction}

Southern Africa is particularly vulnerable to climate change because smallholder subsistence farmers, a majority in the region, rely almost entirely on rain-fed farming (Nhemachena et al. 2010). Weather patterns such as droughts, floods and erratic rainfall impact rural households' food security, nutrition and income, which is significant in a region where the majority of the population are poor and have the lowest adaptive capacity (Beegle et al. 2016; Nhemachena and Hassan 2007). Amongst the most vulnerable are smallholders, especially female farmers who have the least capacity to adapt, and are thus disproportionally impacted by climate change compared to their male counterparts (UN 2009). This high vulnerability to climate change causes food insecurity (recurrent swings between food scarcity and surplus) for up to six million people annually. For example, in the 2015-2016 agricultural season, countries including Lesotho, Malawi, Swaziland, Botswana, Namibia and Zimbabwe declared national emergencies because of drought (WFP 2016). There is an increasing call from farmers, development practitioners and policymakers to recognise drought as the "new normal" in the region, and to respond appropriately (Ajayi et al. 2007a, b). Part of the response is to shift from "relief efforts" (giving food aid to farmers after crop failure) to "production relief"-helping farmers to adopt practices that make them resilient, so they can continue to produce food despite climate change uncertainties.

Innovative partnerships are increasingly recognised as essential for addressing the negative consequences of climate change, however there is limited literature about the practicalities of putting into use innovative partnerships to scale up climateresilient agricultural solutions in southern Africa (Surminski and Leck 2016;

M. A. T. J. Kadzamira $(\bowtie) \cdot$ O. C. Ajayi

The Technical Centre for Agricultural and Rural Co-operation (CTA (ACP-EU)),

Wageningen, The Netherlands

e-mail: kadzamira@cta.int 
Andersson et al. 2016; Fünfgeld 2015; UNEP 2015; Forsyth 2010). The objective of this chapter is therefore to describe the processes and experiences of forming country project teams, partnership models and approaches to reach farmers in Zimbabwe, Zambia and Malawi. This will improve understanding of methods of setting up sustainable partnerships that exist beyond donor-funded projects.

\subsection{Solutions for Scaling CSA}

The specific climate-smart solutions for scaling up were selected over multiple phases, in consultation with farmers and a range of stakeholders including development workers and researchers. The process began with a call for proposals for climate-smart solutions, followed by an evaluation process that involved many experts from Europe, African, Caribbean and Pacific (ACP) countries (CTA 2015). The experts were six individuals from Europe, Africa and the Caribbean; an agroecologist, a climate change scientist, an international agricultural development specialist, and representatives from the farmers' organisation and the Forum for Agricultural Research in Africa (FARA). The top 15 solutions were documented and published to assess their respective development, adoption, impact and potential for being scaled up in other regions, after which four climate-smart solutions were selected (CTA 2015). The project adopts a "bundled solution" approach rather than a single technology. The four climate-smart solutions being scaled up are:

(i) Drought tolerant maize seeds

(ii) Information and communication technology (ICT) enabled weather information services for smallholder farmers

(iii) Weather based index insurance for smallholder farmers

(iv) Diversified options for livestock farmers

\subsection{Partnerships for Scaling Up Climate Resilient Solutions: Country Case Studies}

The scaling up project is currently implemented in three countries: Zimbabwe, Zambia and Malawi (Table 25.1).

\subsubsection{Bilateral Partnership Model: Zimbabwe}

The partnership in Zimbabwe is bilateral, with the two implementing partners, the Zimbabwe Farmers Union (ZFU) and Econet Wireless, sharing common economic interests and equal responsibility. Whilst ZFU acts as the aggregator to reach 
Table 25.1 Summary of country projects

\begin{tabular}{|c|c|c|c|}
\hline Country & Zimbabwe & Zambia & Malawi \\
\hline Project goal & \multicolumn{3}{|c|}{$\begin{array}{l}\text { To contribute to climate resilient agrifood systems that improve food security, } \\
\text { nutrition and income for smallholder farm households under climatic } \\
\text { uncertainties }\end{array}$} \\
\hline Beneficiaries & \multicolumn{3}{|c|}{$\begin{array}{l}\text { 140,000 farmers (approximately } 40 \% \text { female) over } 2 \text { years in Zimbabwe } \\
(30,000) \text { Zambia }(60,000) \text { and Malawi }(50,000)\end{array}$} \\
\hline Regions & $\begin{array}{l}\text { Mashonaland West, } \\
\text { Masvingo, Midlands }\end{array}$ & $\begin{array}{l}\text { Eastern, Central and } \\
\text { Southern Provinces }\end{array}$ & $\begin{array}{l}\text { Southern, Central } \\
\text { and Northern } \\
\text { Regions }\end{array}$ \\
\hline Districts & $\begin{array}{l}\text { Chegulu, Makonde, Zvimba, } \\
\text { Hurungwe, Chivi, Masvingo, } \\
\text { Zaka, Gokwe South, } \\
\text { Shurungwe, Kwekwe }\end{array}$ & $\begin{array}{l}\text { Lundazi, Chipata, Nyimba, } \\
\text { Petauke, Chibombo, } \\
\text { Mumbwa, Kapiri Mposhi, } \\
\text { Serenje, Kalomo, Choma, } \\
\text { Monze, Mazabuka }\end{array}$ & $\begin{array}{l}\text { Zomba, Mchinji, } \\
\text { Nkhotakota, } \\
\text { Ntchisi, Mzimba }\end{array}$ \\
\hline \multirow[t]{4}{*}{$\begin{array}{l}\text { Key } \\
\text { innovations } \\
\text { promoted }\end{array}$} & $\begin{array}{l}\text { Zimbabwe Farmers Union } \\
\text { (ZFU) EcoFarmer Combo: } \\
\text { A service bundle offering } \\
\text { weather information } \\
\text { (including advice for } \\
\text { livestock farmers), } \\
\text { weather index insurance, } \\
\text { payment for ZFU } \\
\text { membership and funeral } \\
\text { cover }\end{array}$ & $\begin{array}{l}\text { Market facilitation: } \\
\text { Better price negotiations } \\
\text { for farmers and links to } \\
\text { seed producers, meat } \\
\text { traders and processors to } \\
\text { smallholders, training } \\
\text { agro-dealers in CSA to } \\
\text { enable them to provide } \\
\text { advice at point of sale }\end{array}$ & $\begin{array}{l}\text { Weather based } \\
\text { index insurance }\end{array}$ \\
\hline & $\begin{array}{l}\text { Agronomic advisory } \\
\text { services via SMS }\end{array}$ & $\begin{array}{l}\text { Awareness campaigns } \\
\text { for farmers to create } \\
\text { demand for drought } \\
\text { tolerant maize seed and } \\
\text { weather based index } \\
\text { insurance }\end{array}$ & $\begin{array}{l}\text { ICT-enabled } \\
\text { weather } \\
\text { information } \\
\text { services for } \\
\text { smallholder } \\
\text { farmers }\end{array}$ \\
\hline & \multirow{2}{*}{$\begin{array}{l}\text { Dial-a-Mudhumeni: A } \\
\text { phone-in facility for crop } \\
\text { and livestock farmers to } \\
\text { get extension advice }\end{array}$} & $\begin{array}{l}\text { Agronomic and animal } \\
\text { husbandry training for } \\
\text { Lead Farmers }^{\mathrm{a}}\end{array}$ & \multirow[t]{2}{*}{$\begin{array}{l}\text { Drought tolerant } \\
\text { maize seeds }\end{array}$} \\
\hline & & $\begin{array}{l}\text { Advisory services for } \\
\text { integrated crop-livestock } \\
\text { farming }\end{array}$ & \\
\hline $\begin{array}{l}\text { Implementing } \\
\text { partners }\end{array}$ & $\begin{array}{l}\text { Zimbabwe Farmers Union } \\
\text { (ZFU), Econet Wireless }\end{array}$ & $\begin{array}{l}\text { Zambia Open University, } \\
\text { Musika Development } \\
\text { Initiatives, Professional } \\
\text { Insurance Company of } \\
\text { Zambia (PICZ) }\end{array}$ & $\begin{array}{l}\text { National } \\
\text { Smallholder } \\
\text { Farmers } \\
\text { Association of } \\
\text { Malawi (NASFAM) }\end{array}$ \\
\hline
\end{tabular}


Table 25.1 (continued)

\begin{tabular}{l|l|l|l}
\hline Country & Zimbabwe & Zambia & Malawi \\
\hline $\begin{array}{l}\text { Other } \\
\text { collaborating } \\
\text { partners }\end{array}$ & $\begin{array}{l}\text { Public sector: } \\
\text { Meteorological Services } \\
\text { Department (MSD), } \\
\text { Government Extension } \\
\text { Service Department, } \\
\text { Zimpost }\end{array}$ & $\begin{array}{l}\text { Public sector: Ministry of } \\
\text { Agriculture (MOA), } \\
\text { National Agricultural } \\
\text { Information Services } \\
\text { (NAIS), MOA Block and } \\
\text { Camp Agricultural } \\
\text { Extension Officers }\end{array}$ & $\begin{array}{l}\text { Public sector: } \\
\text { Department of } \\
\text { Climate Change } \\
\text { and Meteorological } \\
\text { Services (DCCMS) }\end{array}$ \\
\cline { 2 - 4 } & $\begin{array}{l}\text { Private sector: Seed Co, } \\
\text { Pannar Seeds, Klein Karoo } \\
\text { (K2) Seeds, Agriseeds, } \\
\text { aWhere }\end{array}$ & $\begin{array}{l}\text { Private sector: Seed } \\
\text { Companies }\end{array}$ & $\begin{array}{l}\text { Private Sector: } \\
\text { NCO General } \\
\text { Insurance Limited, } \\
\text { Risk Shield } \\
\text { Consultants }\end{array}$ \\
\hline
\end{tabular}

${ }^{a}$ The lead farmer is the main contact for the project and partner organisations. He/she is selected from his/her peers in the community based on educational background as well as standing in the community and is trained (as an entry point to the community). Lead farmers are given training materials, a push bike and a schedule to train or disseminate the information to other farmers in their respective locality

farmers, Econet Wireless provides a platform to digitally register farmers and disseminate information to them. Their shared interest (i.e., reaching farmers with information) and mutually agreed delineation of responsibility (including management of project resources) allows autonomy and ease of operations when carrying out specialised project activities. Additionally, ZFU and Econet Wireless have an equal share of decisive power in project planning, programming and implementation, facilitated by regular project meetings, a joint project implementation plan, and a signed Memorandum of Understanding (MoU). This also supports the management and dissemination of profit from farmer subscriptions to the information services provided. The partners also share an online portal containing project statistics, including farmers' subscriptions to the insurance product, billings and payments.

This second-generation partnership - the two partners have previously worked together in partnership-in Zimbabwe was established in 2015 with the aim of providing farmers with highly valuable services at a minimum cost through ICT. The services, collectively referred to as the original ZFU EcoFarmer Combo, included: crop advice, weather index insurance, payment for ZFU membership and funeral cover. This original combo reached approximately 39,000 farmers by mid 2017.

The current ZFU EcoFarmer Combo costs 1 USD per month and includes all the services in the original version, as well as weather information in real time, toll-free phone information on drought tolerant seeds, and advice for crop and livestock farmers (via the Dial-a-Mudhumeni phone in extension service). With CTA support (especially regarding real-time weather data and increasing reach to farmers) this current combo has reached approximately 10,000 farmers in the first 2 months of mobilization. 
The partnership is mutually beneficial. Organisational theorists have demonstrated that member organisations are most likely to survive if they are able to mobilise resources and demonstrate legitimacy, both of which ZFU achieved through this partnership (Walker and McCarthy 2010). As a member-based organisation which farmers subscribe to, ZFU relies on membership fees for continuity. Before the EcoFarmer Combo was introduced, these were collected manually (i.e., at the district level by ZFU employees and then remitted to ZFU central via a bank deposit), a process that was laborious, inefficient and ineffective. The EcoFarmer Combo package includes the ZFU membership fee and is bought by mobile payment, thereby resolving the issue for ZFU. The partnership also enables ZFU to demonstrate relevance to members through the delivery of tangible, valuable services at a relatively low cost, and reduces cost thanks to their discounted telecom rates from Econet Wireless.

The key benefit for Econet Wireless is that working with ZFU opens up a new clientele of smallholder farmers to which they can market their services, including their insurance products and ICT subscription services. Both organisations profit financially from farmer subscriptions to the EcoFarmer Combo, which ensures that ZFU can exist and that Econet Wireless achieve their commercial goals, both of which are key outcomes for the continuity for the partnership.

The public sector (specifically the Ministry of Agriculture) has also helped facilitate the scale-up of CSA innovations in Zimbabwe. Specifically, farmer recruitment to the ZFU EcoFarmer Combo within Municipal Wards (the smallest political demarcation of a district in Zimbabwe) is supported by local government extension staff. By providing skeptical members of the general public and local (political) leaders with project information, they have played a vital role in validating and legitimising the work of the partnership.

\subsubsection{Multilateral Partnership Model: Zambia}

In Zambia a multilateral partnership comprised of Zambia Open University, Musika Development Initiatives (Musika) and the Professional Insurance Company of Zambia (PICZ) works in collaboration with officers and field workers from the Ministry of Agriculture and Livestock to reduce the vulnerability of smallholder farmers. Specifically, the partnership is working to increase farmers' resilience through diversified, adaptive, climate resilient production systems. Each partner has equal influence in the implementation of the project, achieved through joint regular meetings, field implementation and monitoring. Zambia Open University, by leading the consortium, has ensured government engagement in the project.

Musika previously implemented the DFID-funded project Vuna to promote different aspects of CSA through the creation of a supportive policy environment. They trained farmers and agro-dealers to understand changes in the agricultural landscape, the benefits of using climate smart practices, and the use of pesticides, herbicides and post-harvest technology in an altered environment. 
Musika has capitalised on this previous work in the current partnership by using agro-dealer networks already established and previously trained in CSA.

To ensure sustainability beyond the life of the project, each partner in the Zambian consortium is responsible for the areas in which they specialise. For example, PICZ developed the insurance product for farmers, and provide the digital platform for farmer registration. Musika is responsible for farmer mobilization (sensitising farmers so that they can register for the program) using existing staff and local structures, while Zambia Open University, apart from coordinating and leading project implementation, manages the research components of the project. As in the Zimbabwe partnership described above, there are multiple benefits to this approach for each partner; PICZ acquires new clientele in the form of smallholder farmers, Musika Initiatives (which uses a market facilitation approach to link farmers with agribusinesses) mobilises new farmers for their market linkages work. Zambia Open University benefits from capacity building for their students, field project management experience and research outcomes.

The consortium aims to reach 60,000 farmers in 2 years. Between 2013 and 2015, up to 75,000 smallholders in Zambia were introduced to weather index insurance. In early 2017, the Zambian Government announced a policy that made the purchase of weather index insurance compulsory for all farmers benefiting from the Farmer Input Support Programme (FISP). ${ }^{1}$ Approximately 1.2 million farmers will subscribe to weather index insurance as a result of this policy. The Zambian Government has approached the project consortium to support the implementation of the new policy, and has adopted their training materials on CSA and weather index insurance for use by all front line government extension staff and farmers. Additionally, nationwide efforts to scale up weather index insurance will draw lessons from the consortium target areas. Government buy in, although not a panacea to low adoption and limited access to CSA innovations by smallholders, is of paramount importance in the scale up of climate resilient solutions. Furthermore, the public sector in Zambia plays a key role in the project via the National Agricultural Information Services (NAIS) - the source of all technical agronomic information that the consortium in Zambia intends to disseminate to farmers via mobile phone services during the cropping season. This creates synergies between on-going public services and upcoming private/academic initiatives, such as CTA's work to scale up CRS under discussion. Most importantly, the use of government-approved technical information ensures that farmers do not get conflicting extension service messages from different service providers.

\footnotetext{
${ }^{1}$ The FISP is the Zambian government's programme that distributes subsidised agricultural inputs to small-scale producers of the staple food crop, maize. Started in 2002, the programme benefitted approximately 1.6 Million farmers by 2017.
} 


\subsubsection{Unipolar Partnership Model: Malawi}

Project implementation in Malawi began in the last quarter of 2017. The processes that have thus far taken place have drawn lessons from the Zambian and Zimbabwean consortiums, as summarised in Table 25.2. As the partnership unfolds, there are some insights for consideration in Malawi listed below, particularly for the National Smallholder Farmers Association of Malawi (NASFAM):

(i) Beyond moral persuasion, the opportunity for continuous scaling up of CSA on a sustained basis increases when there are stakeholders who have well defined economic interests and a sound business case to engage in scaling up efforts (i.e., the private sector).

(ii) Strong, vibrant partnerships require transparency, trust, shared influence and decision-making, mutual benefits (economic interests), commitment, recognition of partners' specialised roles and profit sharing.

(iii) Champions are needed to rally the private sector to develop market-driven climate resilient solutions; the government to create an enabling environment; and the farming community to raise awareness of CSA benefits. Strategically placed individuals or institutions in the climate change/agriculture/food security nexus are best suited to act as champions.

(iv) Using field based agricultural extension staff helps the case for scaling up climate resilient solutions. For this to be effective there is need to build capacity of the field staff in key technical areas related to CSA. In the case of NASFAM, this entails building the capacity of Association Field Officers in weather index insurance, drought tolerant seeds and ICT-enabled weather information services.

\subsection{Implications for Development}

The identification of the "best partnership type" for scaling up CSA in southern Africa is not yet conclusive, however some preliminary lessons for successful partnerships can be drawn: they must be inclusive and participatory, have clear mutual benefits, and ensure transparency in project operations. Other enabling factors needed for success include:

1. Private sector involvement: Bringing non-state actors on board effectively improves the chances of successfully scaling up proven innovations (such as CSA) in a sustainable manner. In Zimbabwe, farmers outside the ZFU project have access to similar innovations as the ZFU-EcoFarmer combo because Econet Wireless - as a private commercial entity - is working nationally. In Zambia, PICZ facilitates access to weather index insurance for farmers in the CTA project areas and nationally. Both the Zimbabwe and Zambia case studies show that 


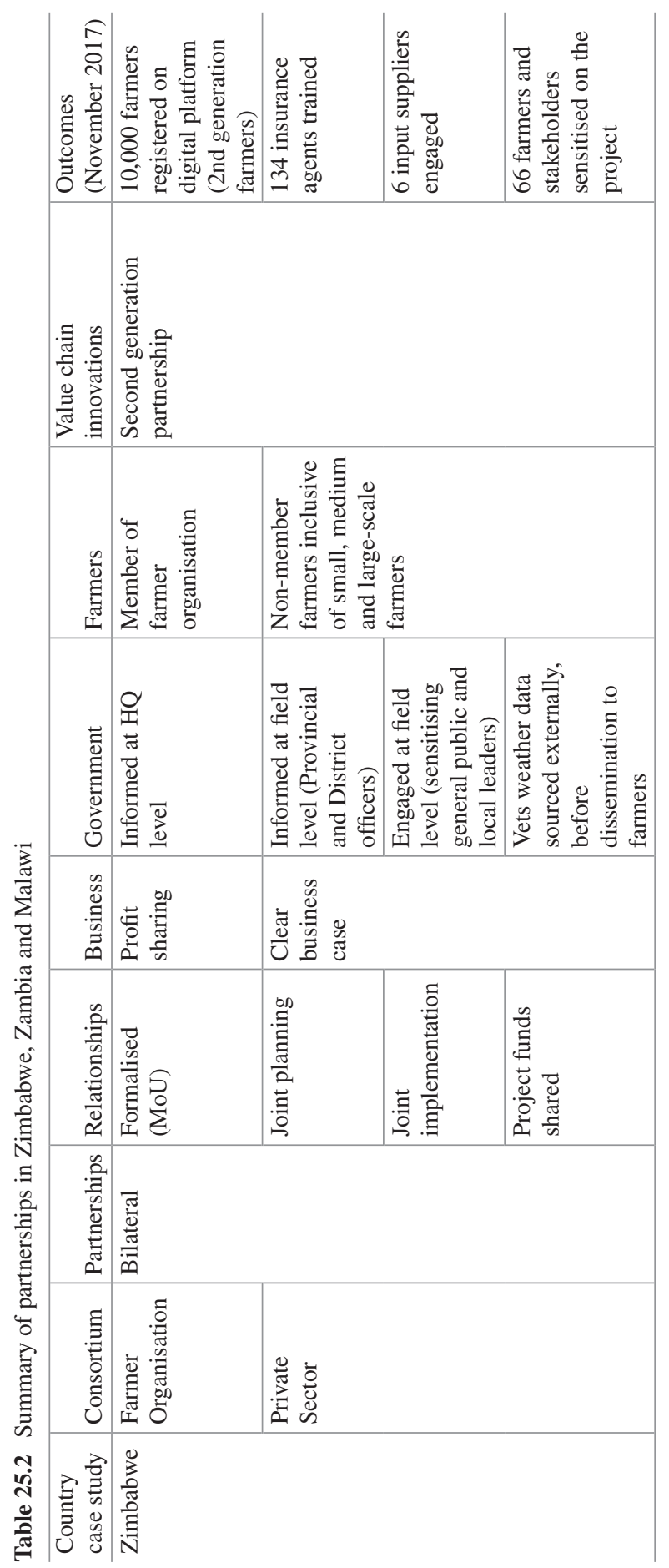




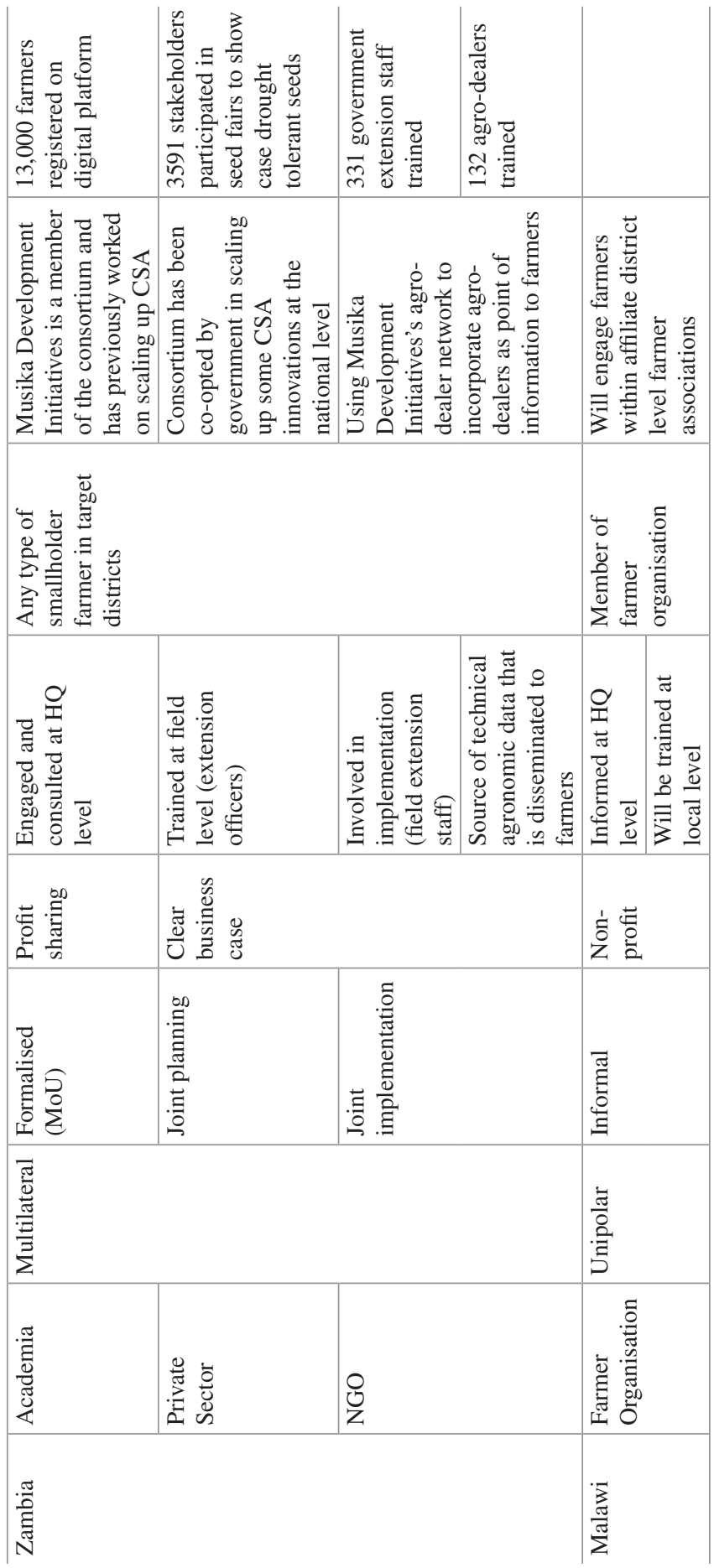


bundled climate resilient solutions will be scaled up by the private sector provided they have commercial viability.

2. Strong and charismatic institutional leadership: this is key to galvanise others into action, and leverage financial incentives.

3. Financial incentives: key for private sector buy in and investment.

4. Make use of existing value chain innovations: partnerships must build on existing and successful mechanisms and processes (e.g., second-generation partnerships in Zimbabwe, engagement of Musika Development Initiatives after their successful implementation of the Vuna project in Zambia).

Beyond the lessons described here, further research is needed to critically assess the challenges associated with scaling up single solutions in relation to bundled solutions, and their impacts on the livelihoods of the poor in a changing climate. Additional research is also needed to better understand how partnerships can be flexible and adaptable in light of the dynamic nature of climate change, and to determine how to better provide clear evidence of a business case for the private sector to invest in scaling up climate resilient solutions. Additionally, action research is needed to monitor and evaluate the extent to which partnerships, such as those explored in this chapter, deliver results and achieve impact.

\section{References}

Ajayi OC, Akinnifesi FK, Gudeta S et al (2007a) Adoption of renewable soil fertility replenishment technologies in southern African region: lessons learnt and the way forward. Nat Resour Forum 31(4):306-317

Ajayi OC, Akinnifesi FK, Sileshi et al (2007b) Economic framework for integrating environmental stewardship into food security strategies in low-income countries: case of agroforestry in southern African region. Afr J Environ Sci Technol 1(4):59-67

Andersson E, Hermelyova S, Pedroni V (2016) Opportunities and challenges for multi-stakeholder partnerships: linking climate change with the post-2015 development agenda. Graduate Institute Geneva. Available from: http://gsogeneva.ch/wp-content/uploads/FINAL-REPORTGSO.pdf

Beegle K, Christiaensen L, Dabalen A et al (2016) Poverty in a rising Africa. World Bank, Washington, DC

CTA (2015) Climate solutions that work for farmers. The Technical Centre for Agricultural and Rural Cooperation (CTA), Wageningen Available from: https://publications.cta.int/media/publications/downloads/1867_PDF_PBBJWiT.pdf

Forsyth T (2010) Panacea or paradox? Cross-sector partnerships, climate change and development. Wiley Interdiscip Rev Clim Chang 1(5):683-696

Füngled H (2015) Facilitating local climate change adaptation through transnational municipal networks. Curr Opin Environ Sustain 12:67-73

Nhemachena C, Hassan R (2007) Micro-level analysis of farmer's adaptation to climate change in Southern Africa, IFPRI Working Paper, vol 714. International Food Policy Research Institute, Washington, DC Available from: http://ebrary.ifpri.org/utils/getfile/collection/p15738coll2/ id/39726/filename/39687.pdf

Nhemachena C, Hassan R, Kurukulasuriya P (2010) Measuring the economic impact of climate on African agricultural production systems. Clim Chang Econ 1(1):33-55 
Surminski S, Leck H (2016) You never adapt alone - the role of multi-sectoral partnerships in addressing urban climate risks. Centre for climate change economics and policy working paper no. 262/Grantham Research Institute on Climate Change and the Environment Working Paper No. 232. Available from: http://www.lse.ac.uk/GranthamInstitute/wp-content/ uploads/2016/03/Working-Paper-232-Surminski-and-Leck.pdf

UN (2009) Women, gender equality and climate change. Fact sheet. United Nations, New York Available from: http://www.un.org/womenwatch/feature/climate_change/downloads/Women_ and_Climate_Change_Factsheet.pdf

UNEP (2015) Collaborating for resilience: partnerships that build disaster-resilient communities and economies. The PSI global resilience project. United Nations Environment Programme (UNEP) Finance Initiative, Geneva Available from: http://www.unepfi.org/psi/wp-content/ uploads/2015/12/collaborating-for-resilience.pdf

Walker ET, McCarthy JD (2010) Legitimacy, strategy, and resources in the survival of communnitybased organizations. Soc Probl 57(3):315-340

WPF (2016) Southern Africa: food security crisis. World Food Programme, Rome Available from: https://www.wfp.org/stories/southern-africa-food-security-crisis-0

Open Access This chapter is licensed under the terms of the Creative Commons Attribution 4.0 International License (http://creativecommons.org/licenses/by/4.0/), which permits use, sharing, adaptation, distribution and reproduction in any medium or format, as long as you give appropriate credit to the original author(s) and the source, provide a link to the Creative Commons license and indicate if changes were made.

The images or other third party material in this chapter are included in the chapter's Creative Commons license, unless indicated otherwise in a credit line to the material. If material is not included in the chapter's Creative Commons license and your intended use is not permitted by statutory regulation or exceeds the permitted use, you will need to obtain permission directly from the copyright holder.

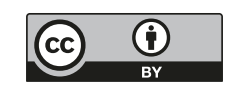

